\author{
Olena Byś \\ Stanisław Kawa
}

\title{
UKRAIŃSKIE USTAWODAWSTWO ABORCYJNE A PRAWO NATURALNE
}

\section{WPROWADZENIE}

„W dniach 16-18 listopada [2020 r.] mija 100 lat, od kiedy władze radzieckie uchwaliły prawo do tak zwanego sztucznego przerywania ciaży. Tym sposobem Związek Radziecki stał się pierwszym na świecie krajem, gdzie zalegalizowano aborcję. Proceder usuwania ciąży w tym kraju osiągnął swoje apogeum w 1964 roku, kiedy to zamordowano 7 milionów nienarodzonych dzieci. Przypominając te smutne fakty, biskupi [ukraińscy] odnieśli się do obecnych czasów, wyrażając swój smutek, że niegodziwe prawo uchwalone w czasach radzieckich, nigdy nie zostało zmienione w niepodległej już Ukrainie. Pasterze Kościoła katolickiego zwrócili uwagę, że od 1991 roku, czyli od ogłoszenia przez Ukrainę niepodległości, w tym kraju zamordowano ok. 30 milionów nienarodzonych dzieci. W liście pasterskim przypomniano, że każda aborcja, tak chirurgiczna, jak i farmakologiczna jest grzechem przeciwko piątemu przykazaniu Dekalogu. Biskupi zachęcili wiernych do modlitwy w intencji nienarodzonych dzieci, a także do praktyki «duchowej adopcji nienarodzonych». Przypomniano także politykom, że zgodnie $\mathrm{z}$ artykułem 27 Konstytucji Ukrainy «każda osoba ma nienaruszalne prawo do życia»" [Krawiec 2020].

S. DR OlENA BYŚ - Sąd Biskupi Diecezji Kamieniecko-Podolskiej; adres do korespondencji: ul. Franciszkańska 2, Kamieniec Podolski 32301, Chmielnicka obl., Ukraina; e-mail: olenabys@ukr.net; https://orcid.org/0000-0003-4845-7846

O. DR STANiSŁaW KAWA - Instytut Teologiczny im. św. Józefa Bilczewskiego we Lwowie; adres do korespondencji: ul. Łyczakowska 49a, 79010 Lwów, Ukraina; e-mail: stankava@gmail.com; https://orcid.org/0000-0002-7622-9376 
W niniejszym artykule zostanie przedstawione tło historyczne legalizacji aborcji na Ukrainie. Punktem wyjścia będzie myśl starożytnych lekarzy, filozofów i prawników, gdyż ta przenikała na tereny historyczne dzisiejszej Ukrainy głównie przez chrystianizację ludów tam zamieszkałych. Przede wszystkim były to wpływy kultury bizantyjskiej, a poniekąd i rzymskiej. Właśnie myśl starożytnych co do aborcji wpływała na formowanie praw książąt Rusińskich po przyjęciu chrztu w IX w.

Warto podkreślić, że współczesna Ukraina bardzo mocno odwołuje się w swej historii do czasów Rusi Kijowskiej. Z tego powodu trzeba wskazać, jaki był stosunek do aborcji w zwyczajach i prawach tego państwa. Natomiast po najazdach mongolskich na terenach wschodnich Rusi powstała Rosja, co niejako wymusza przedstawienie prawodawstwa tego okresu, gdyż wówczas nie istniała jeszcze państwowość ukraińska aż do 1918 r. Natomiast unormowania rosyjskie przedrewolucyjne (do 1917 r.) były stosowane na większości terytorium dzisiejszej Ukrainy.

Więc kolejno po upadku Rusi Kijowskiej, wskutek mongolskich najazdów i wojen książęcych, zostaną przedstawione regulacje wobec analizowanej kwestii od XVI w. w Rosji. Następnie będzie naszkicowana sytuacja prawna w odniesieniu do aborcji w czasach istnienia ZSRR. Tak ujęty kontekst historyczny najlepiej ukaże formowanie myśli prawnej wobec aborcji w dzisiejszej Ukrainie. Można by zarzucić, że nie zostaną scharakteryzowane w aspekcie historycznym prawa zachodnich państw, które stosowały swe ustawodawstwo w kwestii aborcji, gdy władały ziemiami dzisiejszego państwa ukraińskiego. Jednak należy stwierdzić, że te regulacje specjalnie się nie różniły od omawianych, a także nie wpłynęły na współczesne ustawodawstwo ukraińskie, gdyż z przyczyn losowych w tym temacie Ukraina zaczerpnęła ze spuścizny rosyjskiej i sowieckiej. Kolejno przeanalizowane będą obowiązujące regulacje prawne dotyczące aborcji na Ukrainie. Następnie zostanie dokonana ocena obowiązującego stanu prawnego wspomnianej kwestii według norm wynikających z prawa naturalnego.

\section{ABORCJA W STAROŻYTNOŚCI}

Ze starożytności, szczególnie w dziedzinie ginekologii, najbardziej są znane trzy postacie: Hippokrates z Kos (460-370 p. Chr.) oraz zwolennicy jego szkoły Soranos z Efezu (zm. ok. 100 p. Chr.) i Galen z Pergamonu 
(129-199 p. Chr.). Hippokrates, uchodzący za ojca medycyny i etyki medycznej w swej przysiędze stwierdził: „[...] Nikomu, nawet na żądanie, nie podam śmiercionośnej trucizny, ani nikomu nie będę jej doradzał, podobnie też nie dam nigdy niewieście środka na poronienie [...]"1. Proponował natomiast środki aborcyjne, gdy chodziło o usunięcie płodów martwych lub sparaliżowanych, by nie narażać zdrowia i życia matki. Zdecydowanie potępiał zabijanie nienarodzonych dokonywane przez hetery w traktacie O Ciałach, które prowadziły swobodny tryb życia i zajmowały się prostytucja [Nowak 2006, 36-37; Muszala 2009, 91]. Płód uważał za istotę żywa od momentu wykształcenia się narządów. Zaś czas formowania się płodu męskiego określał na ok. 30 dni od momentu poczęcia, a żeńskiego na ok. 42 dni. Czas poruszania się uważał za początek życia (płód męski na trzeci miesiąc, a żeński na czwarty) [Bielas 1991, 37].

Z kolei Soranos wyróżniał środki antykoncepcyjne i poronne twierdząc, że „bezpieczniejsze jest [...] przeszkodzenie poczęciu niż spędzenie płodu”. Natomiast odrzucał medyczne środki aborcyjne, dopuszczał jednak sprowokowanie poronienia w wypadku, o jakim mówił Hippokrates. U Galena także znajdujemy pewne informacje dotyczące aborcji, jednak nie można z cała pewnością stwierdzić, czy chodziło mu o usuwanie płodów martwych czy żywych. Zarówno Soranos, jak i Galen zalecali kobietom w celu aborcji wstrząsy, skoki, ostre potrawy, upuszczanie krwi i nie uważali tego za naruszenie przysięgi Hippokratesa twierdząc, że nie są to środki medyczne.

$\mathrm{W}$ analizowanym zagadnieniu dostrzec warto poglądy Arystotelesa (384322 p. Chr.), który będąc pod wpływem m.in. Hippokratesa uważał, że embrion męski należy uznać za żywy po 40 dniach od poczęcia, zaś embrion żeński po 90 dniach. Przed tym czasem poronienie uznawał za etycznie dopuszczalne. Jego poglądy rzutowały na jego koncepcję idealnego państwa i w kwestii ograniczania liczby dzieci wykluczył możliwość porzucania noworodków, natomiast zalecał przerywanie ciąży na początkowym stadium [tamże, 37-40].

Według niektórych autorów w kwestii dopuszczalności aborcji późniejsze stulecia, w tym całe średniowiecze opierało się na opisach lekarzy z kręgów hipokratejskich - Arystotelesa, Soranosa z Efezu i Galena z Pergamonu [Muszała 2010].

\footnotetext{
${ }^{1}$ Cyt. za: Gula 1991, 197.
} 
Zdaniem stoików (III w. p. Chr.) animacja embrionu ludzkiego następowała $\mathrm{w}$ momencie jego narodzin. Ta teza zakładała bezosobowe traktowanie embrionu ludzkiego w całym okresie prenatalnym, ale nie przełożyła się na pogląd, że spędzanie płodu jest zawsze dozwolone moralnie. Zakładano, że aborcja mogła być przeprowadzona na każdym etapie ciąży, jednak tylko na podstawie przesłanek nieegoistycznych - zagrożenie życia lub zdrowia matki i trudnej sytuacji rodzinnej [Chodorowski 2018, 35-54].

Już w pierwszych wiekach po Chrystusie pojawiały się stanowiska uznające aborcję za crimen. Przedstawiciele poezji łacińskiej, Owidiusz (I w. po Chr.) i Juwenal (II w. po Chr.) wskazują na występowanie tej praktyki, niekaralnej prawem rzymskim, szczególnie w wyższych sferach Rzy$\mathrm{mu}$, na dworze cesarskim. Także mniej lub bardziej ją piętnują. Juwenal nawet pisał o zabójstwie człowieka $\mathrm{w}$ łonie matki (homines in ventre necandos). Wówczas motywem aborcji była chęć ukrycia cudzołóstwa, niechęć ojca do mającego narodzić się dziecka, gwałt, względy terapeutyczne, jak również utrzymanie piękności. Istniała także presja społeczna na dokonanie tego zabiegu, o czym wspominał komediopisarz Plaut (III w. przed Chr.), że Hetera ukrywa się, by nie zostać zmuszona do zabicia swego dziecka (Truculentus 201n.) [Starowieyski 2009, 119-20].

Sprzeciw wobec aborcji wyrażał stoik Seneka (I w. po Chr.) zwracając się do swej matki Helwii słowami: „Nigdy nie wstydziłaś się swego licznego potomstwa, jak gdyby miało niekorzystnie świadczyć o twoim wieku. Nigdy zwyczajem innych kobiet, które szukają chwały w swoich kształtach, nie ukrywałaś ciężarnego łona, jak gdyby nieprzyzwoitego brzemienia, ani nie udaremniłaś poczętych w swoich wnętrznościach nadziei potomstwa"2.

Brakowało wyraźnych antyaborcyjnych norm w prawodawstwie chrześcijańskich cesarzy, jak Teodozjusza Wielkiego czy Justyniana [tamże, 119]. Jednak w kodeksie teodozjańskim (438 r.), który był jednym z najważniejszych zbiorem praw w pierwszych wiekach chrześcijaństwa, nie ma już różnicy między zabójstwem dziecka podlegającego władzy ojcowskiej a zabójstwem dziecka niepodlegającego tej władzy [Wierzbowski 1977, 33]. Rzymianie uważali aborcję nie tyle za przestępstwo przeciwko życiu dziecka, ile przeciw władzy męża i ojca rodziny, który miał prawo oczekiwać

${ }^{2}$ Zob. O pocieszeniu do Helwii 16, 3, tłum. J. Joachimowicz, w: L.A. Seneka, Pisma filozoficzne, t. 1, Wydawnictwo Pax, Warszawa 1965, s. 529. 
od żony, że da mu ona potomstwo. Miał on prawo wnieść skargę przeciwko inicjatorowi aborcji oraz współuczestnikom w tym działaniu [Myszor 2014, 110].

Prawo rzymskie nie zawiera norm antyaborcyjnych. Natomiast idąc za znawcą tej gałęzi prawa - W. Waldsteinem - należy wnioskować, że będąc pod wpływem stoicyzmu bynajmniej nie pozwalało ono na dowolne dysponowanie życiem nienarodzonych, lecz trzeba przyjąć, że przyznawało nienarodzonym nie tylko bierną zdolność posiadania majątku, lecz uznawało ich za podmiot praw, które mogli wykonywać przez kuratora [Rola 1987, 288].

W Digestach Justyniana (528-534 r., łac. Digesta Iustiniani lub Iustiniani Augusti Digesta seu Pandectae) miała zastosowanie paremia nasciturus pro iam nato habetur, quotiens de commodis eius agitur „mającego się narodzić uważa się za narodzonego, ilekroć chodzi o jego korzyści”. W prawie rzymskim w przypadku nasciturusa - dziecka poczętego a nienarodzonego - stosowano fikcję prawną (tzw. warunkową zdolność prawną), czyli mógł być on podmiotem praw i obowiązków, lecz sam nie mógł dokonywać czynności prawnych, pod warunkiem, że urodził się żywy. Ochrona nasciturusa miała i ma zastosowanie głównie w prawie spadkowym - takie dziecko może dziedziczyć3 ${ }^{3}$.

W prawodawstwie pokonstantyńskim pierwsze normy antyaborcyjne $\mathrm{z}$ ich penalizacją zostały zawarte $\mathrm{w}$ kodeksie króla wizygockiego Chindaswinta $(642-653 \text { r. })^{4}$. Aborcję traktowano jako ingerencję w proces rozwoju dziecka w łonie matki oraz oceniano jako naruszenie wszechmocy Bożej. W średniowieczu aborcja została zakazana w każdej postaci. Natomiast w średniowiecznym prawie nie wspomina się o karach za antykoncepcję i przerywanie ciąży [Myszor 2014, 111].

${ }^{3}$ „Qui in utero est, perinde ac si in rebus humanis esset custoditur, quotiens de commodis ipsius partus quaeritur" (D. 1.5.7), https://droitromain.univ-grenoble-alpes. fr/Corpus/d-01.htm\#5 [dostęp: 20.12.2020]; „Płód w łonie matki jest traktowany na równi z człowiekiem już urodzonym, ilekroć chodzi o korzyści samego płodu" [Rozwadowski 1992, 247].

${ }^{4}$ Zob. Book 4, title III: The Visigothic Code: (Forum judicum), The Library of Iberian Resources online, red. S.P. Scott, https://www.documentacatholicaomnia.eu/ 03d/0506-0506,_AA_VV,_Leges_Romanae_Visigotorum_\%5BScott_JP_Curatore\%5D, EN.pdf [dostęp: 20.12.2020], s. 122-23. 


\section{REGULACJE W ZAKRESIE ABORCJI OD CZASU RUSI KIJOWSKIEJ DO POWSTANIA I ISTNIENIA ZSRR NA TERENACH WSCHODNICH DZISIEJSZEJ UKRAINY}

Stosunek do aborcji u ludów słowiańskich na terenach Rusi Kijowskiej z czasów przedchrześcijańskich najczęściej był wyrażony w wierzeniach pogańskich i zwyczajach. Uważano, że noworodek po upływie szóstego tygodnia życia stawał się człowiekiem i wówczas nadawano mu imię. W literaturze na temat wierzeń słowiańskich jest wspominany demon zwany Porońcem, którym stawała się dusza dziecka poronionego lub abortowanego, urodzonego martwym lub zmarłym po porodzie, czy zabitym przez matkę wkrótce po urodzeniu, a pochowanego niezgodnie ze zwyczajem. Były one uważane za potężne demony w związku z posiadaną mocą niezrealizowanego życia [Podgórska i Podgórski 2005, 368; Szyjewski 2004, 195-98]. Podobnie w ukraińskiej mitologii ludowej istnieje demoniczna istota zwana Stradcza, Poterczuk lub Potercza, którym jest dziecko zmarłe jako nieochrzczone [Bilodid 1976, 406; Hrinchenko 1907-1909, 377].

Najstarszym źródłem prawa ruskiego są kroniki informujące o zawieranych w X w. traktatach rusko-bizantyńskich odnoszących się najczęściej do stosunków handlowych między oboma państwami [Sczaniecki 2009, 183-84, 189]. W tym też okresie, będąc pod wpływem Bizancjum, Ruś przyjęła chrzest w 988 r., co też skutkowało tylko nawiązywaniem do pojęć prawa rzymskiego, lecz nie jego asymilacją [Dziadzio 2011, 107; Sczaniecki 2009, 189-90].

W prawach Rusi Kijowskiej od X do XV w. nie znajdujemy kar za dokonanie aborcji, natomiast $\mathrm{w}$ statutach cerkiewnych są przewidziane kary za aborcję i dzieciobójstwo. W tym kontekście V.O. Klyuchevsky przeprowadził badanie związku między grzechem a zbrodnią w okresie obowiązywania Statutów cerkiewnych ${ }^{5}$ św. Włodzimierza (958-1015) i jego syna Jarosława (987-1054) wnioskując: „Kościół zna grzech, zaś zbrodnia jest dla państwa. Kościół uważa każdą zbrodnię za grzech, ale państwo nie uważa każdego grzechu za przestępstwo [...] każde przestępstwo jest grzechem,

\footnotetext{
${ }^{5}$ Pod zbiorczą nazwą „Statutów cerkiewnych” znanych jest kilka grup zbiorów prawa z XI-XV w. Autorami ich byli książęta lub ci, którym to zlecono w imieniu księcia. Przeważnie określały zakres swojej jurysdykcji i źródła materialnego wsparcia Cerkwi. Chronologicznie pierwszym był zapewne tzw. Statut cerkiewny księcia Włodzimierza dotyczący dziesięcin, sądów i osób duchownych [Tolochko 2020].
} 
o ile psuje wolę przestępcy; ale grzech jest przestępstwem, jak bardzo krzywdzi innego lub obraża go i denerwuje społeczność" [Klyuchevsky 2020]. Wobec powyższego należy wnioskować, że aborcja za czasów książęcych była uznawana za grzech w społeczeństwie Rusińskim, nie zaś jako przestępstwo czy zbrodnia. Jednak kobieta, która intencyjnie straciła płód, nazywana była „duszogubem”, czyli była zrównana z mordercą według prawa cerkiewnego. Cerkiew zaś nakładała surowe kary dyscyplinarne na kobiety, które stosowały zioła lub korzystały z usług znachorek (babszeptuch - starszych kobiet zaklinaczek), aby pozbyć się ciąży [Kopylova 2020, 389-92].

Po chrystianizacji prawodawstwo Rusi, w tym Cerkiewne statuty, piętnowały nie tyle zabicie dziecka nienarodzonego, ile dzieciobójstwo w ogóle, pod którym rozumiano też aborcję, gdyż tę ostatnią nierzadko trudno było udowodnić.

W literaturze rosyjskojęzycznej autorzy w kwestii stanowienia prawa antyaborcyjnego często powołują się na postanowienie Soboru Konstantynopolitańskiego IV [Banaszak 1987, 43], zwołanego na przełomie 869 i 870 r. i zwanego prawosławnym, na którym postanowiono w kan. 91, że tak jak mordercy, na taką samą karę zasługują kobiety dopuszczające się przedwczesnego spędzenia płodu przez przyjęcie trucizny [Semashko 1928, 40] . $^{6}$ W tym kontekście należy stwierdzić, że postanowienie soborowe zostało zrealizowane przez wpływ chrześcijaństwa prawosławnego na rosyjskie ustawodawstwo państwowe w XVII w., które obowiązywało na ziemiach wschodnich dzisiejszej Ukrainy, po tym jak hetman Bohdan Chmielnicki zawarł w Perejasławiu unię o włączeniu wspomnianego terytorium do Rosji [Kubala 1910, 47-90].

W rosyjskim imperium kara śmierci za sztuczne przerywanie ciąży została ustanowiona w połowie XVII w. przez cara Alelsieja Michajłowicza Romanowa (1629-1676) w tzw. Sobornym ułożenii [Tikhomirov i Yepifanov 1961, 293], co należałoby przetłumaczyć dosłownie jako „pełny zbiór praw” - swego rodzaju kodyfikacja. Zaś car Piotr I (1672-1725) ukazem z dnia 4 listopada 1715 r. zarządził, aby w celu zapobiegania aborcji i dzieciobójstwa stworzono przy cerkwiach szpitale $\mathrm{z}$ odpowiednimi oknami, gdzie kobiety potajemnie mogłyby zostawiać noworodków [Davidyan i Davidyan 2010, 153]. Także utrzymał w mocy karę śmierci dla matek dzieciobójczyni ${ }^{7}$.

${ }^{6}$ Zob. https://www.kommersant.ru/doc/3011835 [dostęp: 16.12.2020].

${ }^{7}$ Zob. Polnoe Sobranye Zakonov Rossiyskoy Imperii (1713-1719), t. 5, Sanktpeterburh 1830, s. 181. 
Z czasem kwestia prawnego uregulowania dopuszczalności aborcji $\mathrm{w}$ imperium rosyjskim została prerogatywą państwa, co wiązało się z odejściem od wpływu cerkiewnego. Jeszcze w XIX w. w ustawodawstwie rosyjskim aborcja była karalna. W Ułożenii o nakazanijach (zbiór praw o karach) z 1885 r. stwierdza się, że ten kto świadomie, dobrowolnie i umyślnie zastosuje jakiś środek w celu spędzenia płodu, nawet za zgodą brzemiennej kobiety, podlega karze pozbawienia praw majątkowych i przebywaniu w poprawczym areszcie od 5 do 6 lat [tamże, 153].

W.B. Bezgin uważa, że aborcja w ustawodawstwie rosyjskim w II poł. XIX w. i na początku XX w. była zakwalifikowana jako przestępstwo przeciwko osobie. Zgodnie z Utożenijem o nakazanijach z 1845 r. spędzenie płodu zrównano $\mathrm{z}$ dzieciobójstwem i było karane przymusową pracą $\mathrm{w}$ ciężkich warunkach - katorgą od 4 do 10 lat. Zaś w Ugołownym ułożenii (zbiór spraw karnych) z 1903 r. prawodawca złagodził kary za to przestępstwo, stwierdzając, że matka winna zabiciu własnego płodu, podlega karze pozbawienia wolności w zakładzie poprawczym do czasu nieokreślonego powyżej 3 lat, a lekarz - od 1,5 do 6 lat. Zaś prawo cerkiewne tego czasu aborcję uważało za grzech ciężki i za „otrucie płodu ziołami” lub przy pomocy powituch (babki-położnej) nakładano pokutę na okres od 5 do 15 lat [Bezgin 2012, 68], najczęściej zabraniano przyjmowania Eucharystii przez ten okres. Podsumowując należy stwierdzić, że w przedrewolucyjnej Rosji aborcja była prawnie zabroniona.

Po powstaniu Związku Radzieckiego zabiegi przerywania ciąży dopuszczalne były przez prawo w wyniku zalegalizowania aborcji przez bolszewików w 1920 r. Jedną z żarliwych zwolenniczek ówczesnych przepisów w tym zakresie była Aleksandra Kołłontaj, nazwana apostołką wolnej miłości [Davies 2011, 164], radykalna feministka, zwolenniczka i propagatorka „nowej moralności” [Wites 2005, 233].

Pierwsze ustawodawstwo radzieckie regulujące aborcję opierało się na idei bezkarności. W uchwale Ludowego Komisariatu Sprawiedliwości RFSRR z 18 listopada 1920 r. „O ochronie zdrowia kobiet” aborcja została określona jako bezkarna, jeśli została wykonana przez lekarza, w placówce medycznej i nieodpłatnie ${ }^{8}$.

Dnia 4 lipca 1921 r. Ludowy Komisarz Zdrowia i Ludowy Komisariat Sprawiedliwości Ukraińskiej Socjalistycznej Republiki Radzieckiej przyjęli

\footnotetext{
${ }^{8}$ Zob. http://istmat.info/node/42778 [dostęp: 16.12.2020].
} 
analogiczną uchwałę zatytułowaną „O ochronie zdrowia kobiet”, w której stwierdzono, że „rząd radziecki postawił sobie pilne zadanie zwalczania aborcji, która kaleczy kobiety i szkodzi państwu robotniczemu, dla którego jedyną wartością jest praca” [Cherevko 2013, 73].

Należy zauważyć, że w uchwale ukraińskiej, w porównaniu z rosyjską, dodatkowo wprowadza są istotne ograniczenia - aborcja może być wykonywana tylko w pierwszym trymestrze ciąży, a w późniejszym okresie przeprowadzana jest wyłącznie za zgodą konsylium. Zapewniona jest niedopuszczalność aborcji w przypadku przeciwwskazań medycznych. Jak sądzi G.K. Łapko niewykluczone, że idee ukraińskiego ustawodawcy były podstawą norm co do aborcji przyszłego prawa karnego w ZSRR. Główną odmiennością ukraińskiej ustawy od analogicznej rosyjskiej było to, że co do pierwszej prawodawca ustanowił sankcje w postaci prac przymusowych przez okres od 3 do 5 lat [Lapko 2004, 24].

Od 1922 r. odpowiedzialność karna za aborcję była egzekwowana na podstawie art. 142 Kodeksu karnego Rosyjskiej Federacji Socjalistycznych Republik Radzieckich, gdzie zasadniczo powtarza się dekret z 1921 r., jednak sankcje w tym przypadku zostały znacznie złagodzone - prace przymusowe na okres do 6 miesięcy [Murzina 2008, 102].

Dopiero na mocy dekretu Stalina z 1936 r. aborcje, dotąd tak powszechne jak inne zabiegi medyczne, zostały zniesione. Głównym czynnikiem wpływającym na podjęcie tej decyzji była obawa o właściwy przyrost naturalny dla mocarstwa światowego, za które Stalin uznawał ówczesny Związek Radziecki. Po jego śmierci nowe władze postanowiły znów zalegalizować zabiegi aborcyjne. Zaś od 1955 r. przerywanie ciąży stało się zjawiskiem powszechnym oraz ogólnie dostępnym i bezpłatnym ${ }^{9}$. Nie wiadomo, ile dokładnie przeprowadzano aborcji w Związku Radzieckim, ponieważ władze radzieckie nie pozwoliły na publikowanie tych danych w zestawieniach statystycznych. Jednak $\mathrm{z}$ wyliczeń szacunkowych dokonywanych corocznie przez personel medyczny zajmujący się aborcjami wynika, że w niespełna 290 milionowym Związku Radzieckim co roku dokonywano od 6 do 7 milionów aborcji. Zaś pierwsze dane statystyczne na temat usuwania ciąży pochodzą dopiero z czasów pieriestrojki, z których wynika, że

\footnotetext{
${ }^{9}$ Zob. Ukaz Prezidiuma Verkhovnogo Soveta SSSR Ob otmene zapreshcheniya abortov (23.11.1955), w: Vedomosti Verkhovnogo Suda SSSR 22 (1955), s. 425.
} 
w 1988 r. dokonano w Związku Radzieckim prawie 6 milionów zabiegów [Wites 2005, 233-34].

\section{OBOWIĄZUJĄCE REGULACJE PRAWNE DOTYCZĄCE ABORCJI NA UKRAINIE I ICH SKUTKI SPOŁECZNE}

Po przemianach ustrojowych i po uzyskaniu niepodległości przez Ukrainę w 1991 r. nastąpiło zubożenie ludności, co miało negatywne skutki także w kwestii zwiększenia liczby aborcji, w tym i nielegalnych. Nadal obowiązywały normy starego radzieckiego ustawodawstwa. Wspomniane czynniki przyczyniły się do katastrofalnego spadku populacji narodu, wzrostu liczby bezpłodnych kobiet i rodzin bezdzietnych. Uchwała Rady Ministrów z dnia 29 czerwca 1992 r. (nr 431) stwierdza, że Ukraina zajmuje pierwsze miejsce na świecie pod względem liczby aborcji, zaś ponad $12 \%$ małżeństw cierpi na bezpłodność z powodu wcześniejszych aborcji. Uchwała tegoż organu z dnia 13 września 1995 r (nr 736) O krajowym programie planowania rodziny stanowi, że na Ukrainie sztuczna aborcja jest główną przyczyną upośledzenia funkcji rozrodczych i bezpłodności rodzin (22\%), ciężkich procesów zapalnych narządów płciowych (30\%), dalszych powikłań ciąży i porodu, które często prowadzą do śmierci lub patologii niemowląt, a także powodują straty ekonomiczne wynikające z czasowej utraty pracy [Lapko 2004, 24]. Aby zapobiec tak negatywnym społecznie skutkom aborcji ukraiński ustawodawca poczynił starania nowelizacji przepisów w tej kwestii.

W obowiązującej ukraińskiej Konstytucji z 1996 r. ${ }^{10}$ ustrojodawca w art. 3 stwierdza: „Człowiek, jego życie i zdrowie, honor i godność, nietykalność i bezpieczeństwo są na Ukrainie najwyższymi wartościami społecznymi. Prawa i wolności człowieka oraz ich gwarancje określają istotę i kierunek działalności państwa. Państwo odpowiada przed jednostką za swoją działalność. Usankcjonowanie i zabezpieczenie praw i wolności człowieka jest głównym obowiązkiem państwa"11. Powyższe zabezpieczenie prawa do życia - jako jednej z najwyższej wartości - nienaruszalnie przysługuje dziecku nienarodzonemu jednak dopiero po 22. tygodniu ciąży, gdyż ustawo-

${ }^{10}$ Konstytutsiya Ukrayiny (28.06.1996), „Vidomosti Verkhovnoyi Rady Ukrayiny” 30 (1996), s. 141, https://zakon.rada.gov.ua/laws/show//254к/96-вp\#Text [dostęp: 16.12. 2020].

${ }^{11}$ Cyt. za: Toczek 1999. 
dawca w Kodeksie Cywilnym Ukrainy ${ }^{12}$ w art. 281 stwierdza: „Sztuczne przerwanie ciąży, jeśli nie przekracza dwunastu tygodni, może być przeprowadzone na wniosek kobiety. W przypadkach przewidzianych przez prawo aborcję można przeprowadzić w okresie od dwunastego do dwudziestego drugiego tygodnia ciąży. Listę okoliczności, które pozwalają na aborcję po dwunastu tygodniach ciąży, określa prawo"13.

Wspomniane okoliczności umożliwiające dokonanie aborcji w okresie od 12. do 22. tygodnia ciąży zawarte są w rozporządzeniu [postanowa] Gabinetu Ministrów Ukrainy W sprawie wykonania artykułu 281 Kodeksu Cywilnego Ukrainy z dnia 15 lutego $2006 \mathrm{r}$. (nr 144) ${ }^{14}$, które są następujące: niektóre choroby zakaźne i pasożytnicze (różyczka, zakażenie wirusem HIV w IV stopniu zaawansowania, gruźlica); nowotwory (złośliwe nowotwory dowolnej lokalizacji); choroby układu hormonalnego (ciężka cukrzyca, nadczynność przytarczyc, hiperaldosteronizm); zaburzenia psychiczne i behawioralne (demencja naczyniowa, organiczny zespół amnestyczny, niewywołane alkoholem lub innymi substancjami psychotropowymi); choroby układu nerwowego (choroba Alzheimera, dystrofia mięśniowa); choroby układu krążenia (nadciśnienie wtórne, niewydolność serca); choroby układu oddechowego (przewlekła niewydolność oddechowa); choroby układu pokarmowego (niedrożność przełyku, marskość wątroby); choroby układu moczowo-płciowego (wodonercze); choroby układu mięśniowo-szkieletowego i tkanki łącznej; wrodzone wady rozwojowe, deformacje i anomalie chromosomalne; wiek kobiety w ciąży wynosi mniej niż 15 lat lub więcej niż 45 lat; ciąża z powodu gwałtu; początek niepełnosprawności podczas tej ciąży ${ }^{15}$. Trzeba podkreślić, że w ukraińskim ustawodawstwie szeroki wachlarz wyżej wymienionych okoliczności w połączeniu z powszechnie panującą korupcją, dają niemal nieograniczone możliwości dokonywania aborcji, aż do 22. tygodnia ciąży.

${ }^{12}$ Zob. Tsyvil'nyy Kodeks Ukrayiny (16.01.2003), „Vidomosti Verkhovnoyi Rady Ukrayiny" 40-44 (2003), s. 356, https://zakon.rada.gov.ua/laws/show/435-15\#Text [dostęp: 16.12.2020].

13 Tłum. własne.

${ }^{14}$ Zob. https://zakon.rada.gov.ua/laws/show/ 144-2006-п\#Text [dostęp: 16.12.2020].

15 Tłum. własne. Zob. Shtuchne pereryvannya vahitnosti: zhyty za zakonom chy po sovisti?, https://legalhub.online/analityka/shtuchne-pereryvannya-vagitnosti-zhyty-zazakonom-chy-po-sovisti [dostęp: 16.12.2020]. 
Zgodnie z zarządzeniem Ministerstwa Zdrowia z dnia 24 maja 2013 r. (nr 423) $)^{16}$ operacja (procedura) sztucznego przerwania niechcianej ciąży u ciężarnej poniżej 14. roku życia jest przeprowadzana na wniosek jej prawnych przedstawicieli i za zgodą osoby małoletniej zgodnie z art. 284 Kodeksu Cywilnego Ukrainy ${ }^{17}$. Natomiast w art. 134 Kodeksu Karnego Ukrainy ${ }^{18}$ przewidziane są kary za: 1) aborcję dokonaną przez osobę bez specjalnego wykształcenia medycznego (kara grzywny od $850 \mathrm{UAH}$ do $1700 \mathrm{UAH}^{19}$ lub pracami społecznymi na okres od 100 do 240 godzin, albo praca poprawcza do 2 lat lub ograniczenie wolności do 2 lat); 2) przymusowa aborcja bez dobrowolnej zgody ofiary (zagrożona karą ograniczenia wolności do 5 lat lub pozbawienia wolności do 3 lat, pozbawienia prawa do zajmowania określonych stanowisk lub wykonywania określonych czynności do 3 lat lub bez nich); 3) nielegalna aborcja skutkująca długotrwałym złym stanem zdrowia, bezpłodnością lub śmiercią ofiary (zagrożona karą do 5 lat więzienia lub pozbawienia wolności na ten sam okres, pozbawienia prawa do zajmowania określonych stanowisk lub wykonywania określonych czynności do 3 lat lub bez takiego); 4) przymus do sterylizacji bez dobrowolnej zgody pokrzywdzonej osoby (podlega karze ograniczenia wolności do 5 lat z pozbawieniem prawa do zajmowania określonych stanowisk lub wykonywania określonych czynności do 3 lat lub bez nich) ${ }^{20}$.

Należy jednak zauważyć, że pomimo liberalnego ustawodawstwa aborcyjnego, na skutek odradzania chrześcijańskich wartości w świadomości społecznej Ukraińców liczba aborcji spada. Według danych ONZ (World Abortion Policies 2007 i 2013) liczba aborcji na Ukrainie zmniejszyła się ze 109 aborcji na 1000 kobiet w wieku 15-44 lat w 1986 r. do 80,9 w 1991 r., 67,2 w 1996 r. i 27,5 w 2004 r. Od 2010 r. liczba dokonanych aborcji na 1000 kobiet w wieku 15-44 lat stanowi 21,2 przypadków ${ }^{21}$.

${ }^{16}$ Zob. https://zakon.rada.gov.ua/laws/show/z1095-13 [dostęp: 16.12.2020].

17 Tłum. własne: „[...] 2. Osoba, która ukończyła czternaście lat i zgłosiła się na leczenie, ma prawo wyboru lekarza i metody leczenia zgodnie $\mathrm{z}$ jego zaleceniami. 3. Świadczenie opieki medycznej nad osobą fizyczną, która ukończyła czternaście lat, odbywa się za jej zgodą [...]”. Zob. Tsyvil'nyy Kodeks Ukrayiny, stattia 284.

${ }^{18}$ Kryminal'nyy Kodeks Ukrayiny (5.04.2001), „Vidomosti Verkhovnoyi Rady Ukrayiny" 25-26 (2001), s. 131, https://zakon.rada.gov.ua/laws/show/2341-14\#Text [dostęp: 16.12.2020].

${ }^{19} \mathrm{UAH}$ - ukraińska waluta hrywna. Ekwiwalent 7,5 UAH = 1 PLN na dzień 20.12.2020 r.

20 Tłum. własne.

${ }^{21}$ Zob. https://www.un.org/en/development/desa/population/publications/policy/world-abor tion-policies-2013.asp; https://uk.wikipedia.org/wiki/Аборти_в_Україні [dostęp: 16.12.2020]. 
Według doniesień medialnych (2017 r., Deutsche Welle) w ostatnich latach na Ukrainie rocznie wykonywanych jest ponad 100 tys. aborcji, z czego połowa - nie ze względów medycznych, ale na prośbę kobiet. Z kolei w latach 90-tych na Ukrainie zarejestrowano 500 tys. aborcji, a 1990 r. ich liczba przekroczyła 1 mln i wynosiła 21,2 aborcji na 1000 kobiet w wieku 15-44 lat. Według danych Ośrodka Statystyki Medycznej Ministerstwa Zdrowia Ukrainy w 2018 r. na Ukrainie wykonano 46552 aborcji. Z nich 1451 to legalne aborcje z przyczyn medycznych po 12 tygodniach ciąży; 19878 - legalne aborcje medyczne do 12 tygodnia ciąży; 16664 - aborcje przez aspirację próżniową (ekstrakcja płodu specjalnym odsysaniem); 8559 - aborcje medyczne (wykonywane przy użyciu określonych leków) [Pyrih 2019]. Według doniesień medialnych, opartych na relacji Andriya Havryliuka, Dyrektora Departamentu Realizacji Polityki Ministerstwa Zdrowia Ukrainy, w 2019 r. liczba aborcji na Ukrainie według jednostek opieki zdrowotnej podległych Ministerstwu stanowiła 74606 przypadków, z czego 727 wykonano na nieletnich. Dla porównania w 2018 r. na nieletnich wykonano prawie 400 aborcji. Różnica wszystkich aborcji między 2018 r. a 2019 r. wynosi nieco ponad 28 tys., co oznacza, że ich liczba w 2019 r. wzrosła o ok. 60\% [Danilova 2020].

\section{OCENA REGULACJI PRAWNYCH DOTYCZĄCYCH ABORCJI WEDEUG PRAWA NATURALNEGO}

Zanim przystąpimy do oceny ukraińskiego ustawodawstwa w kwestii aborcji, najpierw należy wyjaśnić, czym jest prawo naturalne. „Prawo naturalne (łac. ius naturale) jest zbiorem obiektywnych i absolutnych norm wypływających z natury człowieka i zobowiązujących go do podejmowania działań moralnie dobrych i zaniechania moralnie złych; wyraża ono pierwsze zasady kierujące życiem moralnym, stanowi wyraz pierwotnego zmysłu moralnego pozwalającego człowiekowi rozpoznać rozumem, czym jest dobro i zło" [Petraniuk 2012, 312]. Punktem wyjścia będzie odróżnienie pojęć prawa natury od prawa naturalnego. To pierwsze w naukach przyrodniczych jest synonimem tzw. prawa przyrody, czyli prawidłowości zjawisk przyrody stwierdzonych $\mathrm{w}$ prawach nauki. Termin ten oznacza również same prawa naukowe. Zaś drugie - w tradycyjnych nurtach teologii i filozofii - jest to zespół obiektywnych norm moralnych, wynikających 
z natury człowieka i poznawalnych rozumowo ${ }^{22}$. Jednak w poszczególnych okresach historycznych pod pojęcie prawa naturalnego podkładano rozmaitą treść: teologiczną w poglądach św. Tomasza z Akwinu i inną laicką $\mathrm{w}$ zapatrywaniach przedstawicieli mieszczańskiej szkoły prawa natury w XVII w. W nowożytności do rozwoju myśli prawnonaturalnej przyczyniła się rosnąca popularność myśli liberalnej, która chętnie odwoływała się w początkowym okresie swego kształtowania do pojęć prawa naturalnego czy stanu natury, by w ten sposób uzasadnić potrzebę wolności i swobody działania. Przesiąknięty filozofią oświeceniową, z jej ideą „królestwa rozumu na Ziemi”, wspomniany nurt prawny wywarł wpływ na teorię i praktykę rewolucji amerykańskiej i francuskiej pod koniec XVIII w., przyczyniając się do powstania „koncepcji praw człowieka i obywatela”. Jednak rozwój pozytywizmu prawniczego w XIX w., a następnie normatywizmu i innych doktryn prawnych oraz politycznych (m.in. psychologizmu, socjalizmu, realizmu czy funkcjonalizmu) kontestowało dominację prawa naturalnego w historii myśli prawnej. Warto przypomnieć, że w całym tym okresie prawo naturalne odgrywało ważną rolę w katolickiej nauce społecznej rozwijającej się m.in. pod wpływem neotomizmu. Również w ostatnich stuleciach prawnonaturalne ujęcia doktrynalne miały swoich wybitnych przedstawicieli, z których wymienić warto tych współczesnych: J.M. Finnisa, L.L. Fullera, H.L.A. Harta, F.S.C. Northropa, G. Radbrucha, J. Rawlsa, M.N. Rothbarda, G. Stammlera czy J. Wilda [Maciejewski 2015, 108-109].

Wspomniany neotomizm nawiązuje do koncepcji prawa naturalnego św. Tomasza z Akwinu. Najpierw trzeba przywołać jego sposób pojmowania samego prawa jako lex w traktacie o prawie z części I-II Summa Theologiae: „prawo nie jest niczym innym, jak pewnym rozporządzeniem rozumu dla dobra wspólnego, pochodzącym od tego, komu powierzona jest troska o społeczność, promulgowane"23. Także Akwinata w Summa contra Gentiles stwierdza, że „prawo nie jest niczym innym, jak racją działania, wszelka zaś racja działania zawarta jest w celu”. W arystotelesowskiej tradycji filozoficznej cel działania to „dobro”, które jest racją działania. Wobec powyższego, prawo można opisać jako zespół dóbr [Piechowiak 2006, 395]. Natomiast „prawo naturalne” (ius naturale) św. Tomasza w tymże trak2020].

${ }^{22}$ Zob. https://encyklopedia.pwn.pl/haslo/prawo-natury;4009640.html [dostęp: 16.12.

${ }^{23}$ Cyt. za: Piechowiak 2006, 394. 
tacie zdefiniował następująco: „prawo naturalne nie jest niczym innym, jak uczestnictwem prawa wiecznego w stworzeniu rozumnym" ${ }^{24}$.

Według Jana Pawła II „to przyporządkowanie rozum dostrzega w samym bycie człowieka, rozpatrywanego w świetle całej prawdy o nim, czyli w jego naturalnych skłonnościach, jego dążeniach i celach, mających zawsze także wymiar duchowy: to właśnie one stanowią treść prawa naturalnego, a więc tego uporządkowanego zespołu «dóbr dla osoby», które służą «dobru osoby» - dobru, jakim jest ona sama i jej doskonałość. Tych też dóbr strzegą przykazania, w których według św. Tomasza zawarte jest całe prawo naturalne" ${ }^{25}$. Jednakże idąc po myśli J. Ratzingera [Ratzinger 2004, 1], warto zaznaczyć, że „u źródeł prawa naturalnego nie stoi Kościół. Wpisane jest ono w naturę każdego człowieka. Dlatego stanowi odpowiedź na wyzwania istoty ludzkiej. Tym wyzwaniem jest uznanie, iż człowiek jest podmiotem praw jeszcze przed ustanowieniem jakiegokolwiek prawa ludzkiego. Wszystkie zatem inne prawa powinny dostosowywać się właśnie do tych praw - osoby ludzkiej wynikających z prawa naturalnego, a nie prawa - osoby ludzkiej - do prawa stanowionego" 26 .

Na podstawie powyższego możemy konstatować, że „prawo ludzkie może być prawem tylko $\mathrm{w}$ takiej mierze, $\mathrm{w}$ jakiej pozostaje $\mathrm{w}$ zgodności z prawym rozumem, a co za tym idzie, z prawem naturalnym; w razie sprzeczności prawo stanowione jako niegodziwe staje się aktem przemocy i przestaje być prawem; tak więc ustawodawca nie tylko nie wyjaśnia, ale wręcz zakłamuje obraz rzeczywistości przez negację prawdy o człowieku jako osobie" [Petraniuk 2012, 313-14]. Dlatego też bezpośrednie i umyślne zabójstwo niewinnej istoty ludzkiej jest zawsze aktem głęboko niemoralnym. Stąd „żadna okoliczność, żaden cel, żadne prawo na świecie nigdy nie będą mogły uczynić godziwym aktu, który sam w sobie jest niegodziwy, ponieważ sprzeciwia się prawu Bożemu zapisanemu w sercu każdego człowieka, poznawalnemu przez sam rozum i głoszonemu przez Kościół”27 [Słowikowska 2017, 41-42].

${ }^{24}$ Cyt. za: Piechowiak 2013, 309.

${ }^{25}$ Ioannes Paulus PP. II, Litterae encyclicae cunctis catholicae Ecclesiae episcopis de quibusdam questionibus fundamentalibus doctrinae moralis Ecclesiae Veritatis splendor (06.08.1993), AAS 85 (1993), s. 1133-228; tekst polski w: http://www.vatican. va/content/john-paul-ii/pl/encyclicals/documents/hf_jp-ii_enc_06081993_veritatis-splendor. html\#-3M [dostęp: 16.12.2020], nr 79.

${ }^{26}$ Zob. Słowikowska 2017, 33-50.

${ }^{27}$ Ioannes Paulus PP. II, Litterae encyclicae de vitae humanae inviolabili bono Evangelium vitae (25.03.1995), AAS 87 (1995), s. 401-522; tekst polski w: Encyklika 
W powyższym kontekście warto odnotować, że Stefan Kardynał Wyszyński aborcję nazwał „morderstwem” i „niszczeniem Narodu”. Dlatego, uwzględniając nauczanie Kościoła oraz stanowisko Prymasa Polski, należy stwierdzić, że „aborcja również jest wojną totalną, której celem bądź skutkiem jest ludobójstwo prowadzące do zagłady określonej kategorii ludzi; w tej wojnie nie są stosowane narzędzia militarne, lecz instrumenty medyczne, farmakologiczne, legislacyjne i socjotechniczne" [Taż 2019, 201]. Podobnie wypowiedział się papież Jan Paweł II w 1997 r. w Kaliszu, stwierdzając, że prawo do życia nie jest tylko kwestią światopoglądu, nie jest tylko prawem religijnym, ale jest prawem człowieka. „Natomiast naród, który zabija własne dzieci, jest narodem bez przyszłości”28.

\section{PODSUMOWANIE}

Od czasów starożytnych stosunek do aborcji jednoznacznie był negatywny, jednak była ona dopuszczana w określonych sytuacjach. Prawo rzymskie, które nie zawierało norm antyaborcyjnych, ale będąc pod wpływem stoicyzmu, nie pozwalało na dowolne dysponowanie życiem nienarodzonych. Pierwsze normy antyaborcyjne $\mathrm{z}$ ich penalizacją zostały zawarte w kodeksie króla wizygockiego Chindaswinta (642-653), a aborcję traktowano jako ingerencję $\mathrm{w}$ proces rozwoju dziecka w łonie matki oraz oceniano jako naruszenie wszechmocy Bożej. W średniowieczu aborcja została zakazana w każdej postaci. Jednak w tym okresie nie wspomina się o karach za przerywanie ciąży.

Stosunek do aborcji u ludów słowiańskich na terenach Rusi Kijowskiej z czasów przedchrześcijańskich najczęściej był wyrażony w wierzeniach pogańskich i zwyczajach, w których była identyfikowana ze złem. W najstarszych źródłach prawa ruskiego nie ma kar za aborcję. Natomiast od X w. w cierkiewnych prawach są przewidziane kary za aborcję i dzieciobójstwo. Od XVII w. w imperium rosyjskim była ustanowiona kara śmierci za

Evangelium vitae Ojca Świętego Jana Pawła II do biskupów, do kapłanów i diakonów, do zakonników i zakonnic, do katolików świeckich oraz do wszystkich ludzi dobrej woli o wartości i nienaruszalności życia ludzkiego, Księgarnia Świętego Wojciecha, Poznań $1995, \mathrm{nr} 62$.

${ }^{28}$ Zob. https://lubelski.civitaschristiana.pl/wp-content/uploads/2020/12/Sluga-BozyJan-Pawel-II-Troska-o-Rodzine.pdf [dostęp: 16.12.2020]. 
sztuczne przerywanie ciąży w carskich zbiorach praw. Natomiast od połowy XIX w. spędzenie płodu zrównano z dzieciobójstwem i było karane katorgą lub uwięzieniem. W cerkiewnym prawie tego okresu aborcję traktowano jako grzech ciężki i jako karę nakładano ciężkie pokuty.

Po rewolucji bolszewickiej od 1920 r. w sowieckiej Rosji zalegalizowano aborcję. Dopiero Stalin zakazał aborcji - jako czynnika zaniżającego populacje - dekretem z 1936 r. Wspomniane regulacje dotyczyły tych terytoriów współczesnej Ukrainy, które znajdowały się wówczas w sowieckim imperium. Od 1955 r. przerywanie ciąży w Związku Radzieckim stało się zjawiskiem powszechnym i bezpłatnym. Szacuje się, że co roku dokonywano 6-7 mln aborcji.

We współczesnym ukraińskim ustawodawstwie istnieje szeroki wachlarz okoliczności dopuszczających aborcję, co w połączeniu z powszechnie panującą korupcją, daje niemal nieograniczone możliwości dokonywania aborcji, aż do 22. tygodnia ciąży. Po uzyskaniu niepodległości Ukrainy zauważa się pozytywną tendencję spadku liczny aborcji dzięki odrodzeniu się chrześcijaństwa.

Idąc za Akwinatą, co do kwestii regulacji prawnych dopuszczających aborcję $\mathrm{w}$ odniesieniu do prawa naturalnego należy stwierdzić, że prawo ustanowione przez ludzi o tyle ma moc prawa, o ile wypływa z prawa naturalnego, a jeśli pod jakimś względem sprzeciwia się prawu naturalnemu, nie jest już prawem, ale wypaczeniem prawa. Stąd „prawo do życia przysługuje każdej istocie ludzkiej od samego momentu poczęcia aż do naturalnej śmierci. Podobnie prawna ochrona życia ludzkiego powinna obejmować cały ten okres. Jednak we współczesnym świecie obserwujemy proces legalizacji różnych form zamachu na życie, przybierające chociażby postać aborcji. W tym przypadku życie ludzkie zostaje pozbawione prawno-karnej ochrony w okresie, gdy jest ono najsłabsze i najbardziej zależne od innych" [Wenz 2016, 156-57].

\section{PIŚMIENNICTWO}

Banaszak, Marian. 1987. Historia Kościoła katolickiego. T. 2: Średniowiecze. Warszawa: Akademia Teologii Katolickiej.

Bezgin, Vladymyr B. 2012. Pravovyye obychai i pravosudiye russkikh krest'yan vtoroy poloviny XIX - nachala XX veka. Tambov: FGBOU VPO «Tambovskii gosudarstvyennyi tyekhnichyeskii univyersityet». 
Bielas, Lucjan. 1991. „Dziecko przed urodzeniem w starożytnym świecie pogańskim.” Ruch Biblijny i Liturgiczny 44, nr 1-3:37-41.

Bilodid, Ivan K., red. 1976. Slovnyk ukrayins’koyi movy. T. 7. Kyyiv: Naukova dumka.

Cherevko, Kirilo O. 2013. „Norma pro kryminal'nu vidpovidal'nist' za nezakonne provedennya abortu: istoryko-pravovyy̆ analiz." Visnyk Kryminolohichnoïasotsiatsiï Ukraïny 5:71-76.

Chodorowski, Łukasz. 2018. „Poglądy myślicieli greckich na temat statusu embrionu ludzkiego." W Życie codzienne $w$ starożytności $i$ średniowieczu - doniesienia naukowe, red. Paulina Szymczyk, i Monika Maciąg, 35-54. Lublin: Wydawnictwo Naukowe TYGIEL.

Danilova, Yevheniya. 2020. „Kil'kist' abortiv v Ukrayini u 2019 rotsi zrosla na 60\%.” https:/greenpost.ua/news/kilkist-abortiv-v-ukrayini-u-2019-rotsi-zrosla-na-60-i919 $3 \#: \sim: t e x t=552 \% 20$ переривання\%20вагітності\% 2C\%20з\%20них,3більшилися\%20п риблизно\%20на\%2060\%25\%20відсотків! [dostęp: 16.12.2020].

Davidyan, Ovanes V., i Kira V. Davidyan. 2010. „Istoricheskiye aspekty iskusstvennogo preryvaniya beremennosti (obzor literatury).” Molodoy uchenyy 23, nr 12:151-54.

Davies, Norman. 2003. White Eagle, Red Star: The Polish-Soviet War 1919-20 and the Miracle on the Vistula. London: Pumlico.

Dziadzio, Andrzej. 2011. Powszechna historia prawa. Warszawa: Wydawnictwo Naukowe PWN.

Gula, Janusz. 1991. „Hipokrates a przerywanie ciąży.” W W imieniu dziecka poczętego, red. Jerzy W. Gałkowski, i Janusz Gula, 193-210. Rzym-Lublin: Redakcja Wydawnictw KUL.

Hrinchenko, Borys D., red. 1907-1909. Slovnyk ukrayins'koyi movy. T. 4. Kyyiv: Naukova dumka.

Klyuchevsky, Vasilij O. 2020. „Kurs russkoy istorii. Lektsiya 15.” http://russiahistory. ru/vo-klyuchevskij-kurs-russkoj-istorii-lektsiya-15/ [dostęp: 16.12.2020].

Kopylova, Ksyenia I. 2020. „Stanovleniye norm ob ugolovnoy otvetstvennosti za ubiystvo mater'yu novorozhdennogo rebenka." Molodoy uchenyy 294, nr 4:389-92.

Krawiec, Mariusz. 2020. „Biskupi apelują o ochronę życia nienarodzonych na Ukrainie." https://www.vaticannews.va/pl/kosciol/news/2020-11/biskupi-apepluja-o-ochro ne-zycia-nienarodzonych-na-ukrainie.html [dostęp: 20.11.2020].

Kubala, Ludwik. 1910. Wojna moskiewska R. 1654-1655. Warszawa: Gebethner i Wolff.

Lapko, Heorhij K. 2004. „Istoryko-pravovyy analiz kryminal'noyi vidpovidal'nosti za nezakonne provedennya abortu." W Naukovyy visnyk Chernivets'koho universytetu, Zbirnyk naukovykh prats', Vypusk 212, Pravoznavstvo, red. P.S. Patsurkivsikii, A.A. Kozlovsikii, R.O. Gavrilyuk i in., 24-124. Chernivtsi: Ruta.

Maciejewski, Marek. 2015. „Doktrynalne ujęcia relacji prawo naturalne - prawo stanowione od starożytności do czasów oświecenia." Krakowskie Studia $z$ Historii Państwa i Prawa 8, z. 2:107-32.

Murzina, Larisa I. 2008. „Genezis ugolovnoy otvetstvennosti za detoubiystvo.” Izves tiya Penzenskogo gosudarstvennogo pedagogicheskogo universiteta im. V. G. Belinskogo 11:101-104. 
Muszala, Andrzej. 2009. Embrion ludzki w starożytnej refleksji teologicznej. Kraków: Wydawnictwo WAM.

Muszała, Andrzej. 2010. „Status ludzkiego embrionu w różnych religiach i w historii.” https://www.mp.pl/etyka/poczatki_zycia/53006,status-ludzkiego-embrionu-w-roznych -religiach-i-w-historii [dostęp: 14.12.2020].

Myszor, Jerzy. 2014. „Prawno-społeczne aspekty zabójstw dzieci narodzonych i aborcji na Śląsku w latach 1742-1914.” Roczniki Nauk Prawnych 24, nr 4:109-24.

Nowak, Maria. 2006. „Pozycja prawna i obyczajowa heter w Atenach epoki klasycznej.” W Formy organizacji życia społecznego $w$ starożytności, red. Adam Gendźwiłł, Adam Izdebski, Damian Jasiński, i in., 33-41. Poznań: Wydawnictwo Poznańskie.

Petraniuk, Juliusz. 2012. „Prawo naturalne.” W Encyklopedia Katolicka, t. 16, 312-14. Lublin: Towarzystwo Naukowe KUL.

Piechowiak, Marek. 2006. „Prawo naturalne a prawa człowieka.” W Zadania wspótczesnej metafizyki. T. 8: Substancja. Natura. Prawo naturalne, red. Andrzej Maryniarczyk, Katarzyna Stępień, i Paweł Gondek, 394-409. Lublin: Polskie Towarzystwo Tomasza z Akwinu.

Piechowiak, Marek. 2013. „Tomasza z Akwinu koncepcja prawa naturalnego. Czy Akwinata jest myślicielem liberalnym?” Przeglad Tomistyczny, t. 19, 301-37.

Podgórska, Barbara, i Adam Podgórski. 2005. Wielka Księga Demonów Polskich. Leksykon $i$ antologia demonologii ludowej. Katowice: Wydawnictwo Kos.

Pyrih, Volodimir. 2019. „MOZ oprylyudnylo informatsiyu pro kil'kist' abortiv v Ukrayini u 2018 rotsi. V Ukrayini prodovzhuye zmenshuvatysya kil'kist' abortiv." https://zaxid.net/moz_oprilyudnilo_informatsiyu_pro_kilkist_abortiv_v_ukrayini_u_ 2018_rotsi_n1478536 [dostęp: 16.12.2020].

Ratzinger, Joseph. 2004. „Pensieri cardinali. Ratzinger e Galli Della Loggia su storia, politica e religione." Il Foglio Quotidiano 297:1.

Rola, Marcin. 1987. „Ochrona nienarodzonych w prawie rzymskim.” Prawo Kanoniczne 30, nr 1-2:287-88.

Rozwadowski, Władysław. 1992. Prawo rzymskie. Zarys wykładu wraz z wyborem źródet. Poznań: Ars Boni et Aequi.

Semashko, Nikolaj A., red. 1928. Bol'shaya Meditsinskaya Entsiklopediya. Moskva: Sovyetskaya entsiklopyediya.

Sczaniecki, Michał. 2009. Powszechna historia państwa i prawa. Warszawa: Lexis Nexis.

„Shtuchne pereryvannya vahitnosti: zhyty za zakonom chy po sovisti?” 2019. https:// legalhub.online/analityka/shtuchne-pereryvannya-vagitnosti-zhyty-za-zakonom-chy -po-sovisti [dostęp: 16.12.2020].

Słowikowska, Anna. 2017. „Aborcja po urodzeniu w kontekście prawa naturalnego.” Journal of Modern Science 35, nr 4:33-50.

Słowikowska, Anna. 2019. Postulaty Stefana Kardynała Wyszyńskiego $w$ nauczaniu Soboru Watykańskiego II. Źródła inspiracji dla kościelnego prawa konstytucyjnego i publicznego. Lublin: Towarzystwo Naukowe KUL.

Starowieyski, Marek. 2009. „Aborcja i życie nienarodzonych w starożytności chrześcijańskiej." Warszawskie Studia Teologiczne 22, nr 2:117-47. 
Szyjewski, Andrzej. 2004. Religia Słowian. Kraków: Wydawnictwo WAM.

Tikhomirov, Mihail N., i Petr. P. Yepifanov. 1961. Sobornoye ulozheniye 1649 goda. Moskva: Izdatyelistvo Moskovskogo univyersityeta.

Toczek, Ewa, tłum. 1999. Konstytucja Ukrainy. Warszawa: Wydawnictwo Sejmowe.

Tolochko, Oleksij P. 2020. „Statuty tserkovni.” http://www.history.org.ua/?termin =Statuty_tserkovni [dostęp: 16.12.2020].

Wenz, Wiesław. 2016. „Ochrona życia dziecka poczętego.” Kościót i Prawo 5 (18), nr 2:127-65.

Wierzbowski, Błażej F. 1977. Treść władzy ojcowskiej w rzymskim prawie poklasycznym. Władza nad osobami dzieci. Toruń: UMK.

Wites, Tomasz. 2005. „Zróżnicowanie przestrzenne aborcji w Rosji.” W Społeczne skutki globalizacji - globalizacja a bezpieczeństwo i zdrowie publiczne, red. Izabella Łęcka, 233-42. Warszawa: Wydawnictwo UW.

\section{Ukraińskie ustawodawstwo aborcyjne a prawo naturalne}

\section{Streszczenie}

W niniejszym artykule przedstawiono tło historyczne legalizacji aborcji na Ukrainie. Punktem wyjścia jest myśl starożytnych lekarzy, filozofów i prawników, gdyż ta przenikała na tereny historyczne dzisiejszej Ukrainy głównie przez chrystianizację. Przede wszystkim były to wpływy kultury bizantyjskiej, a poniekąd i rzymskiej. Współczesna Ukraina odwołuje się w swej historii do czasów Rusi Kijowskiej. Z tego powodu $\mathrm{w}$ artykule przybliżono stosunek do aborcji w zwyczajach i prawach tego państwa. Po upadku Rusi Kijowskiej przedstawiono regulacje od XVI w. w Rosji. Następnie naszkicowano sytuację prawną w odniesieniu do aborcji w ZSRR. W tym temacie Ukraina również zaczerpnęła ze spuścizny rosyjskiej i sowieckiej. Kolejno przeanalizowano obowiązujące regulacje prawne na Ukrainie, a także dokonano oceny obowiązującego stanu prawnego według norm wynikających z prawa naturalnego.

Słowa kluczowe: aborcja; prawo naturalne; Ukraina

\section{Ukrainian Abortion Law and Natural Law}

\section{Summary}

This article presents the historical background of the legalization of abortion in Ukraine. The starting point for the discussion is reference made ancient physicians, philosophers, and jurists, whose ideas penetrated the historical territories of today's Ukraine mainly through Christianization. They mostly absorbed Byzantine and, in a way, Roman culture. Historically, contemporary Ukraine is considered the successor of Kievan Rus. For this reason, the attitude to abortion in the customs and laws of that historic state is discussed. After Kievan Rus, the authors analyse regulations on abortion in force in the 16th-century Russia. Next, the legal same question is discussed 
against the legal solutions adopted in the Soviet Union era. Ukraine used to adopt the Russian and Soviet legacy in this respect. Finally, the contemporary legal regulations regarding abortion in Ukraine is discussed. The current legal status of abortion in the country is juxtaposed against the norms of natural law.

Keywords: abortion; natural law; Ukraine

Information about Author: DR. OlenA BYŚ - Bishop's Court of the KamieniecPodolia Diocese; correspondence address: ul. Franciszkańska 2, Kamieniec Podolski 32301, Chmielnicka obl., Ukraine; e-mail: olenabys@ukr.net; https://orcid.org/00000003-4845-7846

Information about Author: REV. DR. STANISŁAW KAWA - Theological Institute St. Joseph Bilczewski in Lviv; correspondence address: ul. Łyczakowska 49a, 79010 Lwów, Ukraine; e-mail: stankava@gmail.com; https://orcid.org/0000-0002-76229376 